\title{
Optimising The Replacement of Lard with Palm Stearin (PS) In Frankfurter-Type Beef Sausage Batters
}

\author{
Akwetey WY*, Boakye DS and Awuni BY \\ Department of Animal Science, College of Agriculture and Natural Resources, Ghana
}

*Corresponding author: Akwetey WY, Department of Animal Science, College of Agriculture and Natural Resources, Kwame Nkrumah University of Science and Technology, Kumasi, Ghana.
Received Date: April 17, 2019

Published Date: May 06, 2019

\begin{abstract}
This experiment was conducted to determine the suitability of palm stearin (PS) and the effects of its inclusion on physico-chemical properties and consumer acceptability of frankfurter-type beef sausages. PS was substituted for lard at $0 \%$ (control), $25 \%, 50 \%, 75 \%$ and $100 \%$ to obtain 5 treatments respectively coded as $\mathrm{PS}_{0}, \mathrm{PS}_{25}, \mathrm{PS}_{50}, \mathrm{PS}_{75}$, and $\mathrm{PS}_{100}$. A 36-member consumer panelist evaluated the sausages based on appearance, flavor, tenderness, juiciness, mouth feel, aftertaste and acceptability, using a 7-point Hedonic Scale (1= dislike very much, 4= intermediate, 7= like very much). There were significant $(\mathrm{p}<0.05)$ increases in the temperature of sausage emulsions as the level of PS usage increased. The temperature of sausage batters increased from $6.20^{\circ} \mathrm{C}\left(\mathrm{PS}_{0}\right)$ to $11.40^{\circ} \mathrm{C}\left(\mathrm{PS}_{100}\right)$. Percentage cooking yields ranged from $89.90 \%\left(\mathrm{PS}_{0}\right)$ to $94.43 \%\left(\mathrm{PS}_{25}\right)$, but the observed differences were however not statistically different. Also, no significant $(\mathrm{p}>0.05)$ differences existed between sensory parameters of sausages produced with or without PS. There were significant differences $(\mathrm{p}<0.05)$ in water holding capacity and $\mathrm{pH}$ of the raw products but no significant differences ( $\mathrm{p}>0.05$ ) were observed for the cooked products. Water holding capacity (raw) ranged from 53.33\% ( $\mathrm{PS}_{0}$ ) to $66.67 \%\left(\mathrm{PS}_{100}\right)$, while water holding capacity (cooked) was between $24.67 \%\left(\mathrm{PS}_{75}\right)$ and $33.33 \%\left(\mathrm{PS}_{25}\right.$ and $\left.\mathrm{PS}_{50}\right)$. Raw batter pH ranged from $6.12\left(\mathrm{PS}_{100}\right)$ to $6.27\left(\mathrm{PS}_{25}\right)$ and $\mathrm{pH}$ (cooked) was between $6.25\left(\mathrm{PS}_{100)}\right.$ and $6.32\left(\mathrm{PS}_{0}\right)$. The cost of producing frankfurters reduced from $\mathrm{GH} 12.45\left(\mathrm{PS}_{0}\right)$ to $\mathrm{GH} 10.31\left(\mathrm{PS}_{100}\right)$ per $\mathrm{kg}$. It was concluded that palm stearin has promising potential to replace portions of lard in frankfurter-type beef sausages because sausages containing $100 \%$ palm stearin were similarly scored in all eating qualities just as the control with $100 \%$ lard.
\end{abstract}

Keywords: Palm stearin; Lard; Frankfurter-Type beef sausage; Sensory parameters; Physico-chemical properties

\section{Introduction}

In ancient times, sausage making was one of the traditional ways of preserving meat or prolonging the shelf life of meat when there were no alternative means to prevent spoilage. However, this act has graduated from being mere preservation of meat to provision of economically nutritious products to consumers. Like frankfurters, different traditional sausages have been manufactured over the years with varying tastes and flavor, suitable to a broad spectrum of consumers across the globe. According to FAO [1] processed meats like frankfurters are produced by comminuting meat ingredients, with or without some non-meat ingredients to obtain a uniform ground meat with an acceptable liking to consumers. Ordinarily, tallow and lard have been the main sources of fat in most processed meat products. Upon cooking, fats stabilize the overall protein matrix and interacts with other ingredients to develop texture and prevent shrinkage [2]. Also, fat in meat serves an important role in aroma and taste development, and thus enhances the overall sensory quality of processed meats [3]. According to Miles [4], a reduction of the fat content in processed meat products to less than $20 \%$ results in an unacceptable product flavor, appearance and texture. However different technologies, and ingredients such as cowpea [5] and other plant products such as vegetable oils [6] and solar-dried plantain flour [7], at different levels of inclusion have been used in the production of low-fat meat products without loss of eating characteristics. Plant fats are potential alternatives for animal fat which contains relatively higher amounts of lowdensity lipoproteins popularly called "bad" cholesterol [8]. These compounds which are waxy in nature are synthesized within animal tissues but are absent in plants. Studies have shown that palm stearin, a component of oil palm which is solid at ambient temperature and has the highest melting point of $44^{\circ} \mathrm{C}$ is obtained by partial crystallization at controlled temperatures [9]. Palm stearin is white to yellow in appearance, neutral in flavor and is more variable in composition than palm olein which has a higher amount of unsaturation and exists as liquid at room temperature [10], for which reason it is bottled and sold as cooking oils. Due to the solid nature of palm stearin and its related solid fat contents 
which are made up of free fatty acids of palmitic acid, it has more variable physical characteristics than palm olein. As a result, it is used as a component in making interesterified fat such as margarine and vegetable ghee [11]. Apart from its edible purposes, it has properties for making animal feeds and soaps. Furthermore, palm stearin also is relatively priced lower than tallow and could potentially be a positive substitute for lard as far as health aspects of consumers of emulsion-type sausages are concerned. Hence the objective of this study was to produce frankfurter-type beef sausage using palm stearin as a substitute for lard; and evaluate their cost of production, physico-chemical properties and consumer acceptability.

\section{Materials and Methods}

\section{Experimental location and sources of ingredients}

The experiment was carried out at the Meat Science and Processing Unit of the Department of Animal Science, Kwame Nkrumah University of Science and Technology (KNUST), Kumasi. Palm stearin was obtained from the Juaben Oil Mills Limited, Kumasi. Other dry non-meat ingredients used in the preparations were purchased from the Ayeduase market in Kumasi. Boneless beef and lard were obtained respectively from the Kumasi Abattoir Company Limited and the Meat Science and Processing Unit of Department of Animal Science, KNUST.

\section{Preparation of sausages}

The formulation and process of sausage preparation was according to the method proposed by Deda et al. [12]. Once a meat batter of desirable consistency was prepared, it was stuffed into $26 \mathrm{~mm}$ natural casings using a manual filler machine. The sausages were hand-linked at $6 \mathrm{~cm}$ lengths and smoked in a smoke house for $1.5 \mathrm{hr}$ using firewood. The smoked sausages were scalded in 70 ${ }^{\circ} \mathrm{C}$ water to attain internal temperature of $65^{\circ} \mathrm{C}$, after which they were cooled using running tap water for 30 minutes, drained for 10 minutes, and refrigerated at $2{ }^{\circ} \mathrm{C}$ in for further studies and quality analysis.

\section{Parameters Measured}

\section{Cooking yield (CY \%)}

Cooking yield was determined for each treatment using the Equation proposed by [13]. The cooked and uncooked sausages were weighed, and the cooking yield was calculated as weight of cooked sausage sample divided by weight of uncooked sausage multiplied by 100 .

\section{Acidity (pH) and water holding capacity (WHC) of raw and cooked sausages}

The procedure used in the determination of $\mathrm{pH}$ (raw and cooked) was as described by Akwetey [5]. Five (5) grams of mashed samples of each treatment was mixed thoroughly with $10 \mathrm{ml}$ of deionized distilled water in separate centrifuge tubes. The mixtures obtained were allowed to stand for 15 minutes after which a $\mathrm{pH}$ meter was lowered into each, in order to read and record the pH using a Syntax pH meter (Schott Instruments lab 860). The procedure was repeated three times for each treatment at the Agricultural Biotechnology Laboratory- KNUST. The procedure of Lin and Huang [14] was used in determining the water holding capacity of the experimental products.

\section{Sensory attributes}

Sensory evaluation of sausage attributes was performed by thirty-six (36) untrained consumer panelists. Samples were evaluated in three (3) sessions in order to minimize communication among panelists. Ten (10) pieces of sausage from each treatment were taken out of the freezer and thawed at room temperature under a ceiling fan. The treatment samples were then sliced equally and placed in baking pans that were labelled appropriately according to treatments and heated in a hot-air oven (Wagtech, model: GP50SSF25001G, UK) at 70oC for ten (10) minutes. Sausage samples were turned after five (5) minutes during heating to ensure even distribution of heat. The warmed sausage samples were placed on plates coded with three-digit random numbers in order to ensure uniform and independent sampling and to avoid prejudiced assessment of the products. The panelists were asked to assess samples based on tenderness, juiciness, flavour, mouth feel, color, aftertaste and overall acceptability using a 7-point hedonic scale ( 1 = dislike very much, 2 = dislike much, 3 = dislike slightly, 4= intermediate, $5=$ like slightly, $6=$ like much and $7=$ like very much). Water was provided to the panelists to rinse their mouth before starting and between sample evaluations in order to avoid the influence of the sensory attribute of one sample on the other.

\section{Statistical Analysis}

All data generated from the study were subjected to Analysis of variance (ANOVA) using SPSS (Statistical Package for Social Science) (2006) version 16.0 for windows. A Complete Randomized Design (CRD) was used and significant differences between treatment means were obtained using Duncan's test of homogeneity at $5 \%$.

\section{Results and Discussion}

\section{Temperature, cooking yield, water holding capacity and acidity (pH)}

The results for temperature, cooking yield, water holding capacity (raw and cooked) and $\mathrm{pH}$ (raw and cooked) of frankfurtertype beef sausage with and without palm stearin are shown in Table 1. Temperature increased significantly $(p<0.05)$ with frankfurter-type beef sausages containing palm stearin in their formulation (Table 2). The values for temperature of the sausage emulsions ranged between $6.20\left(\mathrm{PS}_{0}\right)$ and $11.40\left(\mathrm{PS}_{100}\right)$. According to Nusantoro, [15], palm stearin has higher melting temperature (TM: $46.7^{\circ} \mathrm{C}$ ) than lard (TM: $30.0^{\circ} \mathrm{C}$ ). Temperature changes that took place within the batters could be due to gain or loss of energy when physical or chemical changes occur (Table 1).

Excessive temperature rise in the bowl cutter could result in emulsion break down, however the observed meat batter temperatures did not exceed $16^{\circ} \mathrm{C}$ as recommended by FAO [1]. The cooking yield of frankfurters depends on the cooking temperature [16], cooking time [17], the ingredients [18], and the amount of fat 
in the products [19]. However, no significant differences ( $p>0.05)$ were observed for cooking yields in this study. In Table 1, treatment $\mathrm{PS}_{100}$ recorded the highest WHC while $\mathrm{PS}_{0}$ had the least in emulsion (raw) state but in the cooked sausages no significant differences were observed in WHC. A higher WHC in a sausage shows important characteristics of juiciness and tenderness when subjected to mastication. Grinding of meat increases WHC by enhancing the number of polar protein groups available for binding with water molecules [20]. Common salt and food grade polyphosphates are extensively used in many meat products due to their desirable effect on WHC and other functional properties of meat [21]. The $\mathrm{pH}$ of raw sausage batters ranged from $6.13\left(\mathrm{PS}_{100}\right)$ to $6.27\left(\mathrm{PS}_{25}\right)$ while the cooked sausage $\mathrm{pH}$ was between $6.30\left(\mathrm{PS}_{25}\right)$ and $6.25\left(\mathrm{PS}_{100}\right)$. No significant differences $(\mathrm{p}>0.05)$ were observed in the $\mathrm{pH}$ of $\mathrm{PS}_{0}, \mathrm{PS}_{25}, \mathrm{PS}_{50}$ and $\mathrm{PS}_{75}$ but treatment $\mathrm{PS}_{100}$ recorded a significantly lower $\mathrm{pH}(\mathrm{p}<0.05)$ compared to all. It was observed that the $\mathrm{pH}$ for sausage batters increased for all the treatments upon cooking but there were no significant differences ( $p>0.05)$ among them (Table 2).

Table 1: Temperature of sausage batters, cooking yield, water holding capacity and acidity $(\mathrm{pH})$.

\begin{tabular}{|c|c|c|c|c|c|c|c|}
\hline \multirow{2}{*}{ Parameter } & \multicolumn{7}{|c|}{ Type of Sausage } \\
\hline & $\mathrm{PS}_{0}$ & $\mathbf{P S}_{25}$ & $\mathrm{PS}_{50}$ & $\mathrm{PS}_{75}$ & PS $_{100}$ & P-value & SEM \\
\hline Temperature* $\left({ }^{\circ} \mathrm{C}\right)$ & $6.20^{\mathrm{a}}$ & $6.90^{\mathrm{b}}$ & $8.23^{c}$ & $10.43^{\mathrm{d}}$ & $11.40^{\mathrm{e}}$ & 0 & 0.535 \\
\hline pH (raw) & $6.23^{\mathrm{b}}$ & $6.27^{b}$ & $6.24^{\mathrm{b}}$ & $6.22^{\mathrm{b}}$ & $6.12^{a}$ & 0 & 0.015 \\
\hline pH (cooked) & 6.32 & 6.3 & 6.29 & 6.26 & 6.25 & 0.11 & 0.1 \\
\hline WHC (raw) (\%) & $53.33^{\mathrm{b}}$ & $56.00^{\mathrm{b}}$ & $60.67^{a}$ & $64.00^{\mathrm{a}}$ & $66.67^{\mathrm{a}}$ & 0 & 6.152 \\
\hline WHC (cooked) (\%) & 28.67 & 33.33 & 33.33 & 24.67 & 27.33 & 0.11 & 4.073 \\
\hline Cooking yield (\%) & 89.9 & 94.43 & 91.17 & 89.47 & 91.27 & 0.67 & 1.055 \\
\hline
\end{tabular}

a b c d eMeans in the same row with different superscripts are significantly different $(p<0.05)$. Control PS $=0 \%$ Palm stearin, $P S_{25}=25 \%$ palm stearin, $\mathrm{PS}_{50}=50 \%$ palm stearin, $\mathrm{PS}_{75}=75 \%$ palm stearin, $\mathrm{PS}_{100}=100 \%$ palm stearin. *temperature of sausage batter.

Table 2: Sensory attributes of beef type frankfurter sausages with or without palm stearin.

\begin{tabular}{|c|c|c|c|c|c|c|c|}
\hline \multirow{2}{*}{ Parameter } & \multicolumn{7}{|c|}{ Type of Sausage } \\
\cline { 2 - 8 } & PS $_{\mathbf{0}}$ & PS $_{\mathbf{2 5}}$ & PS $_{\mathbf{5 0}}$ & PS $_{75}$ & PS $_{\mathbf{1 0 0}}$ & P- value & SEM \\
\hline Appearance & 5.27 & 5.22 & 4.92 & 5 & 4.92 & 0.77 & 0.118 \\
\hline Flavour & 5.49 & 5.41 & 5.27 & 5.22 & 4.76 & 0.24 & 0.108 \\
\hline Tenderness & 5.05 & 5.38 & 5.16 & 5.06 & 4.86 & 0.68 & 0.109 \\
\hline Juiciness & 5.32 & 5.38 & 5.24 & 5.22 & 4.92 & 0.64 & 0.1 \\
\hline Mouthfeel & 5.22 & 5.41 & 5.22 & 5.24 & 4.84 & 0.58 & 0.109 \\
\hline Aftertaste & 5.22 & 5.22 & 5.32 & 5.35 & 4.65 & 0.24 & 0.11 \\
\hline Acceptability & 5.54 & 5.54 & 5.35 & 5.59 & 5.39 & 0.19 & 0.105 \\
\hline
\end{tabular}

Control $\mathrm{PS}_{0}=0 \%$ palm stearin, $\mathrm{PS}_{25}=25 \%$ palm stearin, $\mathrm{PS}_{50}=50 \%$ palm stearin, $\mathrm{PS}_{75}=75 \%$ palm stearin, $\mathrm{PS}_{100}=100 \%$ palm stearin. Sensory scale: $1=$ Dislike very much; $7=$ Liked very much.

\section{Sensory attributes}

Results obtained for the sensory attributes studied are shown in Table 2. No significant ( $p>0.05$ ) differences were obtained for all the sensory parameters evaluated for sausages produced with or without palm stearin, though the acceptability of the $75 \%$ palm stearin-treated beef sausages seemed to be slightly higher compared to all the other sausage types.

\section{Cost of production}

Table 3: Cost of ingredients used in sausage production with and without palm stearin.

\begin{tabular}{|c|c|c|c|c|c|}
\hline \multirow{2}{*}{ Parameter } & Type of Sausage & & & & \\
\hline & $\mathrm{PS}_{0}$ & $\mathrm{PS}_{25}$ & $\mathrm{PS}_{50}$ & $\mathbf{P S}_{75}$ & $\mathrm{PS}_{100}$ \\
\hline Boneless beef & 65.46 & 65.46 & 65.46 & 65.46 & 65.46 \\
\hline Lard & 13.2 & 9.9 & 6.6 & 3.3 & 0 \\
\hline Palm stearin & 0 & 0.18 & 0.36 & 0.54 & 0.72 \\
\hline Total cost & 78.66 & 75.54 & 72.42 & 69.3 & 66.18 \\
\hline Cooked weight (kg) & 6.32 & 6.64 & 6.41 & 6.29 & 6.42 \\
\hline Cost of Production $(\mathrm{GH} \Phi) / \mathrm{kg}$ & 12.45 & 11.38 & 11.3 & 11.02 & 10.31 \\
\hline Percentage change & & 8.59 & 9.24 & 11.49 & 17.19 \\
\hline
\end{tabular}

Control $\left(\mathrm{PS}_{0}\right)=0 \%$ palm stearin, $\mathrm{PS}_{25}=25 \%$ palm stearin, $\mathrm{PS}_{50}=50 \%$ palm stearin, $\mathrm{PS}=75 \%$ palm stearin, $\mathrm{PS}_{100}=100 \%$ palm stearin respectively in place of lard. 
A simple analysis based on retail price of the ingredients used in product formulations and yield recorded for each treatment revealed that the costs (GHథ) per kg were respectively 12.45, 11.38, 11.30, 11.02 and 10.31 for $\mathrm{PS}_{0}, \mathrm{PS}_{25}, \mathrm{PS}_{50}, \mathrm{PS}_{75}$ and $\mathrm{PS}_{100}$ (Table 3). Increasing inclusions of palm stearin decreased the cost of production which could most probably be due to the fact that palm stearin is relatively cheaper compared to lard. From Table 3, the cost of producing $1 \mathrm{~kg}$ of beef-type frankfurter using $75 \%$ palm stearin as a replacer of lard reduced by $11.49 \%$. This is substantial, and more profit could be made by manufacturers who may engage in beef-type frankfurter production using palm stearin as a replacer for lard without compromising eating quality as revealed by the sensory evaluation performed in this study (Table 3).

\section{Conclusion and Recommendations}

The results of the experiment suggest that palm stearin deserves attention as a potential hard fat of vegetable origin to replace lard in sausage production. Costs of producing sausages reduced with increasing levels of palm stearin. Water holding capacity and $\mathrm{pH}$ of cooked sausage were not influenced by using palm stearin in the manufacture frankfurter-type beef sausages. More so, the use of palm stearin as lard replacer did not affect cooking yield and sensory properties of the sausages. It is therefore recommended that further work should be undertaken using palm stearin in other types of sausage. Such studies should include determination of proximate composition, fat and moisture retention of sausages produced with or without palm stearin in place of lard.

\section{Acknowledgment}

None.

\section{Conflicts of Interest}

No conflicts of interest.

\section{References}

1. Food and agriculture organization of the United Nations (2007) Meat Processing Technology for Small-to Medium-Scale Producers Bangkok Pp. 19-25.

2. Brewer MS (2012) Reducing the Fat Content in Ground Beef without Sacrificing Quality. A review: Meat Science 91(4): 385-395.

3. Webb EC, Oneill HA (2008) The fat paradox and meat quality. Meat Science 80(1): 28-36.

4. Miles RS (1996) Processing of low-fat meat products. Proceedings of 49th Reciprocal Meat Conference. American Meat Science Association Chicago Pp. 17-22.
5. Akwetey WY, Oduro IN, Ellis WO (2013) Whole cowpea (Vigna unguiculata) flour as non-conventional extender in meatloaf. Food Bioscience 5: 42-46.

6. Youssef MK, Barbut S (2011) Physicochemical effects of the nature of the lipid phase and protein level on meat emulsion stability, texture and microstructure. Journal of Food Science 75(2): 108-114.

7. Akwetey WY, Yamoah GA (2013) Producing Low-Fat Pork Patties with Solar-Dried Plantain (Musa Acuminate) Flour. Journal of Animal Science Advances 3(4): 150-156.

8. Tuso PJ, Ismail MH, Ha BP, Bartolotto C (2013) Nutritional update for physicians: plant-based diets. The Permanente Journal 17(2): 61-66.

9. Lim TK (2010) Edible Medicinal and Non-Medicinal Plants. Journal of Health Sciences Pp 338.

10. Gunstone F (Ed) (2011) Vegetable oils in food technology: composition, properties and uses. John Wiley \& Sons.

11. Mamat H, Aini IN, Said M, Jamaludin R (2005) Physic-chemical characteristics of palm oil and sunflower oil blends fractionated at different temperatures. Food Chemistry 91(4): 731-736.

12. Deda MS, Bloukas JG, Fista GA (2007) Effect of tomato paste and nitrite level on processing and quality characteristics of frankfurters. Meat Science 76(3): 501-508.

13. Yang HS, Choi SG, Jeon JT, Park GB, Joo ST (2007) Textural and sensory properties of low-fat pork sausages with added hydrated oatmeal and tofu as texture-modifying agents. Meat Science 75(2): 283-289.

14. Lin K, Huang HY (2003) Konjac or gellan gum mixed gels improve the quality of reduced- fat frankfurters. Meat Science 65(2): 749-755.

15. Nusantoro BP (2009) Physicochemical Properties of Palm Stearin and Palm Mid Fraction Obtained by Dry Fractionation. Agritech 29(3): 154158.

16. Kim SH, Chin KB (2007) Physico-chemical properties and changes of sarcoplasmic protein bands of chicken meat cuts with or without salt during cooking temperature. Korean Journal of Animal Science and Technology 49(2): 269-278.

17. Banon S, Diaz P, Nieto G, Castillo M, Alvarez, D (2008) Modeling the Yield and Texture of Comminuted Pork Products Using Color and Temperature. Effect of Fat/Lean Ratio and starch. Meat Science 8(3): 649-655.

18. Huang SC, Shiau CY, Liu TE, Chu CL, Hwang DF (2005) Effects of Rice Bran on Sensory and Physico-Chemical Properties of Emulsified Pork Meatballs. Meat Science 70(4) 613-619.

19. Hughes E, Cofrades S, Troy DJ (1997) Effects of Fat Level, Oat Fiber and Carrageenan on Frankfurters Formulated with 5, 12 and 30\% Fat. Meat Science 45(3): 273-281.

20. Hamm R, (1985) The effect of water on the quality of meat and meat products: Problems and research needs. In Properties of water in Foods, Springer, Dordrecht, USA, pp. 591-602.

21. Huffman DL, Cross HR, Campbell KJ Cordray JC (1981) Effect of Salt and Tripolyphosphate on Acceptability of Flaked and Formed Hamburger Patties. Journal of Food Science 46(1): 34-36. 